\title{
Achebe's defense of civilized Ibo culture via proverbial language in Things Fall Apart
}

\author{
Gohar Ayaz ${ }^{1}$, Nadia Anjum² \\ ${ }^{1}$ HEC PhD Scholar, BZ University, Multan, Pakistan \\ ${ }^{2}$ Fauji Foundation Model School, Abbottabad, Pakistan
}

\begin{abstract}
This paper is an attempt to explore the proverbial language of Chinua Achebe in Things Fall Apart in support of the civilized Ibo culture. Chinua Achebe has put many proverbs in his mouth pieces. All the proverbs used in this novel belong to the Ibo culture. The proverbs used by Ibo people in the novel are worthy enough to claim that they have a strong heritage and history which is symbol of civilized culture. The language of the Ibo people when compared with whites, it becomes crystal clear that whatever they say is proved or followed by strong arguments of proverbs. Whites say things imperatively and lack strong arguments in their talks. The questioning of Ibo people during their discussions with whites is as rich as their day to day conversations. Language is one of the basic traits of a culture, the culture having language saturated with proverbs and rich vocabulary is considered to be civilized culture. Ibo language is rich in both these aspects therefore it is presented as a civilized and strong culture not mere the culture of barbarians as considered by the West. This is a text-oriented study which is focused on the language of Things Fall Apart in which proverbs are used in abundance and the purpose of this paper is to prove that Chinua Achebe wants to reveal the civilized side of Africans in general and Ibo people in particular.
\end{abstract}

Keywords-Achebe, Civilized, Culture, Ibo, Language, Proverb.

\section{INTRODUCTION}

Albert Chinualumogu Achebe was born on November 16, 1930 in the very unstable country of Ogidi, Nigeria. He was exposed to missionaries early in his childhood because Ogidi was one of the first missionary centers established in Eastern Nigeria and his father was an evangelist. Yet it was not until he began to study at the University of Ibadan that Achebe discovered what he himself wanted to do. He had grown appalled to the superficial picture of Nigeria that many non-Nigerian authors were providing. That is when Achebe resolved to write something that viewed his country from the inside. (Gallagher, 2010, p. 260) His first novel, Things Fall Apart, achieved exactly the same. Things Fall Apart is based on Nigeria's early experiences with the British. It is the story of an Ibo village and one of its great men, Okonkwo, who is a very high achiever being a champion wrestler, a wealthy farmer, a husband to three wives, and a man with titles. Okonkwo's world is disrupted with the appearance of the first white man who tries to inflict his religion on the Umuofia natives. Okonkwo, a high tempered man, later kills a British employed man and eventually takes his own life.

Proverbs could be described as short, popular witty sayings with words of advice or warning. Proverbs could also be viewed as a repository of native intelligent, code of moral laws and philosophy of both life and social justice. Proverb is a short repeated witty statement of experience which is used to further a social end (Yufus, 2004). He in his other paper writes, "Short, cleverly constructed belief statements which are used to perform different functions in society. One of such functions is to help users to say unpleasant things in an ameliorated way" (Yusus, 2004). They are able to do this because proverbs are often associated with common or traditional i.e. longstanding wisdom or attitude. So proverbs reveal the civilized and intellectual side of a culture. Those works of literature which are rich in its language are the true representation of a particular culture.

\section{RATIONAL OF THE STUDY}

Achebe has used a lot of proverbs in his novel Things Fall Apart. Whenever he wants to show the wisdom of his Ibo people he puts strong language in their mouths. Some examples from the text are here which shows the abundant use of proverbs in this novel. A man who pays respect to the great paves the way for his own greatness." (Achebe, 1994, 19) Here Okonkwo explains why he has come to Nwakibie, "An old woman is always uneasy when dry bones are mentioned in a proverb" (Achebe, 1994, p. 21). Here Okonkwo remembers his own father. In context of a joke about someone who refused to honor his father's shrine with a fowl. "The lizard that jumped from the high iroko tree to the ground said he would praise himself if no one else did" (Achebe, 1994, p. 21). In this proverb Okonkwo explains his capacity for hard work before Nwakibie, his sons and neighbors. "Those whose palm-kernels were cracked for them by a 
benevolent spirit should not forget to be humble." (Achebe, 1994, p. 26) This proverb explains Okonkwo's arrogance in calling Osugo a "woman" at the meeting of the people. "The Earth cannot punish me for obeying her messenger" (Achebe, 1994, p. 67) "A child's fingers are not scalded by a piece of hot yam which its mother puts into its palm" (Achebe, 1994, p. 67). Here is an explanation of Okonkwo's role in Ikemefuna's death. "As the elders said, if one finger brought oil it soiled the others" (Achebe, 1994, p. 125) Obierika's mourning over Okonkwo's exile, but his rationale that one could not ignore offenses against the earth. "Living fire begets cold, impotent ash." (Achebe, 1959, p. 151) Here is Okonkwo's analysis of the conversion of his degenerate and effeminate son, Nwoye. "A man danced so the drums were beaten for him" (Achebe, 1994, p. 185) Rev. Smith's intransigence and hostility towards anything traditional is there in this proverb. "Whenever you see a toad jumping in broad daylight, then you know that something is after its life." (Achebe, 1994, p. p. 203) It is said at the meeting of Umuohia after the imprisonment of the six elders. "Eneke the bird was asked why he was always on the wing and he replied: "Men have learned to shoot without missing their mark and I have learned to fly without perching on a twig" (Achebe, 1994, p. 204).

Achebe himself once said, "Language is a weapon and we use it, and there's no point in fighting it." (Gallagher, 2010, p. 260) These are words that Achebe lives by. He stood by this statement throughout his entire career with a language style that would change African literature was no exception. He accomplished his goal by writing about his own culture and his own family in a poetic, proverbial style. The unique language style of Things Fall Apart not only changed Achebe's career, but it also changed his country. Achebe himself once said that Art is, and always was, at the service of man. Our ancestors created their myths and told their stories for a human purpose. Any good story, any good novel, should have a message, should have a purpose. Achebe used the 'weapon' of language to convince 'outsiders' that Nigeria is a nation with great potential. One prominent method that Achebe uses for convincing the Europeans of Nigeria's potential was writing his novel in English and then using the African language within passages. He uses his English knowledge for " infiltrating the ranks of the enemy and destroying him from within," while his native language forces readers to" look outside of their constraints and identify more with the African culture." He was quoted as saying that "It doesn't matter what language you write in, as long as you write it good," and that is what he did (Gallagher, 2010, p. 260).

When Achebe writes about Okonkwo's father, he writes, "Even as a little boy he had resented his father's failure and weakness, and even now he still remembered how he had suffered when a playmate had told him that his father was agbala."(Achebe, 1994, p. 13) A reader may not know what agbala means first hand, but then Achebe goes on to say that agbala is a word for "a man who had taken no title."

Another example is when he writes, "I don't know why such a trifle should come before the egwugwu", using the African dialect in conversation. (Achebe, 1994, p. 94) By doing this, he uses his language to first draw the reader in with one's own language and then show them an "inside" view like no writer ever had before. The "enemy", the Europeans could easily see from the mere intelligence of the author that Nigeria had potential. The story is set in Umuofia, which in Nigeria is translated into Bush Children, bush meaning uneducated and uncivilized. The Igbo were to be civilized by British standards, under British rule, using the British language, and the Anglican religion. Achebe chose Umuofia to represent the opinion Europeans held that the natives of Nigeria are a "tribe of "uncivilized savages". Achebe proves that this theory is purely ignorant with his use of Igbo proverbs.

The novel contains several native sayings that represent the strong religion, morals, and culture of the country. An example is seen early on in the novel when Achebe writes, "If a child washed his hands he could eat with kings," referring to Okonkwo, who 'washed his hands' of his bad reputation which came because of his father's lifestyle. (Achebe, 1994, 8) This is parallel to Nigeria's circumstances, and implies that if Nigeria 'washed their hands' the country could be just as important as Britain. A second example of Achebe's preverbal language is Okonkwo is asking Nwakibie for yam seeds and he says, "The lizard that jumped from the high iroko tree to the ground said he would praise himself if no one else did" (Achebe, 1994, p. 21). These few words show that the Umuofians had a great sense of pride, and if used properly if could result in great accomplishments.

The strong religious beliefs of the tribe are clearly seen when Achebe writes, "Those whose palm kernels were cracked for them by a benevolent spirit should not forget to be humble," showing that they try to be thankful for everything that they have. (Achebe, 1994, 26) Also, Achebe goes on to write, "When a person says yes, his Chi (personal God) says yes to him," (p. 27) this implying that the natives believed that if you humble yourself to your God he will not say no to you. Finally, he also uses the proverb "A man that makes trouble for others also makes trouble for himself," (p. 28) this being similar to the Golden Rule that the British knew and were very familiar with. These proverbs say the exact opposite 
of the European opinion, providing evidence that this highly religious, moral culture is civilized. A third method that Achebe puts to use is having his characters tell traditional folk tales. This shows Europeans that the natives have a great amount of pride for their country, and it draws the readers in by using something that they are familiar with doing themselves. The most apparent example is when Ekwefi told Enzima a story about a selfish, greedy tortoise. She begins the same way as the Europeans might begin a story to a child, saying 'Once upon a time'. She goes on to tell the story of a tortoise who overheard that there was a great feast for birds approaching, and he wanted to go. After begging for wings from a bird, the tortoise goes to the feast and tricks the birds, getting all of their food. The consequences are high, as the birds get revenge and the tortoise's shell is scarred forever, as the story provides the lesson to not be greedy and selfish. (Achebe, 1994, p. 99) Here, the European's theory is once again proved wrong.

Chinua Achebe was the first to truly develop an African style of writing (Alimi, 2012, 122). This statement has proved true in each of Achebe's novels and Things Fall Apart is no exception. He has even been called the father of African literature. He used this tool to achieve something that he wanted to do since his college days, and show the Europeans that they were wrong. Achebe once said, "One big message of the many that I try to put across is that Africa was not a vacuum before the coming of Europe, that culture was not unknown in Africa, and that culture was not brought to Africa by the white world." (Gallagher, 2010, p. 261) He did exactly this by drawing readers in with the familiarity of the English language and traditional folk tales and then showing them his own culture by writing with an advanced African vocabulary and knowledge of Ibo proverbs. He achieved something that no other writer had done before him. It not only changed his career but it also changed the careers of many writers to come. Chinua Achebe set out with a purpose and in accomplishing it he changed the entire literary world. Today he is paralyzed from a car crash and only makes seldom appearances, but for Nigerians and Europeans he will not be forgotten any time soon.

Prior to British colonization, the Igbo people as depicted in Things Fall Apart lived in a patriarchal collective political system. Decisions were not made by a chief or by any individual but rather by a council of male elders. Religious leaders were also called upon to settle debates reflecting the cultural focus of the Igbo people. The Portuguese were the first Europeans to explore Nigeria. Though the Portuguese are not mentioned by Achebe, the remaining influence of the Portuguese can be seen in many Nigerian surnames. The British entered
Nigeria first through trade and then established The Royal Niger Colony in 1886. The success of the colony led to Nigeria becoming a British protectorate in 1901. The arrival of the British slowly began to deteriorate the traditional society. The British government would intervene in tribal disputes rather than allowing the Igbo to settle issues in a traditional manner. The frustration caused by these shifts in power is illustrated by the struggle of the protagonist Okonkwo in the second half of the novel.

Despite converting to Christianity himself, Achebe wrote Things Fall Apart not only in response to the then common bastardizations of his native people, but to show his fellow citizens that the Igbo were dignified. His mentioning of the Igbo people's democratic institutions and culture serve to test them "against the goals of modern liberal democracy and to have set out to show how the Igbo meet those standards." (Rhodes, 1993, p. 61) While the Europeans in Things Fall Apart are depicted as intolerant of Igbo culture and religion, telling villagers that their gods are not real (Achebe, 1994, p. 135) the Igbo are seen as tolerant of other cultures as a whole. For example, Uchendu is able to see "what is good among one people is an abomination with others" (Achebe, 1994, p. 129).

However, the novel does not simply idolize the Igbo people, as Achebe also intended to show readers what fractures existed within the Igbo people's culture. He "Also presents its weaknesses which require change and which aid in its destruction." (Rhodes, 1993, p. 61) He depicts the injustices of Igbo society. No more or less than Victorian England of the same era, the Igbo are a patriarchal society. They also fear twins, who are to be abandoned immediately after birth and left to die of exposure. The novel attempts to repair some of the damage done by earlier European depictions of Africans. In addition, Achebe chooses to ignore the evidence of what Izevbaye calls 'rich material civilization' in Africa in order to portray the Igbo as isolated and individual, evolving their own 'humanistic civilization' (Lindfors, 1991) This suggests that Achebe intended to show readers what the Igbo culture could have taken advantage of or eliminated in order to survive in future years. (Rhodes, 1993, p. 62)

Achebe writes that European sentiments toward Africans are mistaken. According to Diana Akers Rhoads (1993) the most important mistake of the British is their belief that all civilization progresses, as theirs have, from the tribal stage through monarchy to parliamentary government (p. 62). On first arriving in Mbanta, the missionaries expect to find a king (Achebe, 1994, p. 138), and, discovering no functionaries to work with, the British set up their own hierarchical system which 
delegates power from the queen of England through district commissioners to native court messengers, foreigners who do not belong to the village government at all (Achebe, 1994, p. 160). Since the natives from other parts of Nigeria feel no loyalty to the villages where they enact the commands of the district commissioners, the British have superimposed a system which leads to bribery and corruption rather than to progress." (Rhodes, 1993, p. 63) By contrast, the Igbo follow a democracy which judges each man according to his personal merit.

In the previous postcolonial works of literature, which were written from the point of views of colonizers and by colonizers, Africans were dehumanized and were declared barbaric and uncivilized. Africans are always referred to having no voice. They are shown as silent as animals. Their culture and religions were neglected or ridiculed. Charlotte Bronte represents Bertha Masson, an African woman as silent oppressed character. Charles Dickens and Thackeray are criticized by Edward Said for marginalization of the colonizers. The most severe attack on the status of the African came from Joseph Conrad in the form of Heart of Darkness. In this novella Conrad shows that Africans have no culture. He did so to show that they are not civilized. His black characters would never speak. They are shown as barbaric with no language.

To answer this bitter attack Achebe wrote his master piece Things Fall Apart in which he proved that Africans are not uncivilized. He revealed their culture and religion and most importantly he gave voice to the blacks. Though he wrote about Ibo culture in particular but his theme was universal. He knew that language is the strong tool for propagation of a motto. He was an active participant in African Movement. He used English language because he wanted to show his culture to the West. He was, in-fact writing back to the empire. His characters are strong both physically and mentally. $\mathrm{He}$ explored their cognitive power through their language. The language of a culture shows its antiquity and civilized nature. Proverbs are considered to be the essence of a language. A language full of proverbs is considered to be old and historic. It shows the wisdom of the people of that culture. Every character of Okonkwo has powerful language full of proverbs. They are not illiterate who do not know how to live a human life. They are poured with wisdom and intellect.

When Umofians have an encounter with the Whites who propagate their religion claiming to obey on God they were not aware of the intellect of the blacks who could put such tough questions which would shackle their pre conceptions about the. Umofians asked them that if they propagate one God then what about the concept of their Trinity. This was the question which is not asked by any great scholar but a common Ibo man.

Ibo culture is considered to be one of the oldest and developed cultures of Nigeria. It is as perfect as any other great culture of white people. It is not only the name of certain barbaric events but it belongs to the most civilized people. Its clan leadership system, religion, marriages, deaths and specially language are the complex ones. Their language has a large vocabulary and it is rich with proverbs. All the proverbs used in this novel are taken from Ibo culture. They are just translated into English so that the West may know what each proverb means.

Achebe wants to remove the misconception of white people in general and some novelists in particular. He uses every now and then the proverbs from the Ibo culture. Ibo culture is presented as a civilized one because he was aware of the fact that a civilized culture has strong language and a strong language has abundance of proverbs. He put so many proverbs in the mouth of his characters to give voice to them. In a way he tries to answer Gayatri Chikarborty Spivak who question can Subaltern speak? His answer is yes he/she/they can. They are not mere puppets who have no feelings and emotions. They are not mere silent spectators like animals but they have the language and can speak and speak well. Their witty language is full of references so their discussions are authentic not like those generalizations of Bronte or Conrad.

\section{CONCLUSION}

Achebe's novel Things Fall Apart is an encounter of Conrad's Heart of Darkness. Many misrepresentations of Conrad are criticized and answered in this novel. Conrad did not give even voice to the natives of Africa. He wanted to show that they are not civilized beings so they must be silent as animals. Though the setting of his novel is the country of blacks yet he ignores their culture and language. Achebe in his novel support the civilized nature of Africans that is why he not only gives voice to each of his characters but also put a language full of witty proverbs in their mouths. He wants to prove the natives as wise men. Wise man never lives a life of barbarism. They must have grown in a civilized culture that is why they talk so. This research is an insight into Achebe's support of the culture of the African natives. It will furnish a way for the new researchers to explore other traits in his support of a civilized culture. They may discover the same trait of proverbial language in other novelists as well. 


\section{REFERENCES}

[1] Achebe, Chinua. (1994). Things Fall Apart. New York: Anchor Books

[2] Alimi, S. A. (2012). A Study of the Use of Proverbs as a Literary Device in Achebe's Things Fall Apart and Arrow of God. International Journal of Academic Research in Business and Social Sciences. 2(3), pp. 121-127.

[3] Gallagher, S. (2010). Linguistic Power: Encounter with Chinua Achebe. The Christian Century. New York: State Writers Institute. pp. 260-271.

[4] Lindfors, B. (ed). (1991). Approaches to Teaching Achebe's Things Fall Apart. New York: Anchor Books

[5] Obiechina, E. (1992). Narrative Proverbs in the African Novel. Oral Tradition, 7(2), pp. 197-230.

[6] Rhoads, D. A. (1993). Culture in Chinua Achebe's Things Fall Apart. African Studies Review. 36(2), pp. 61-72.

[7] Yusuf, Y. K. (2004). Linguistic sources of Euphemism. Journal of English Studies, 1, Ibadan: University of Ibadan. 